International Journal of Advanced Academic Research (Sciences, Technology and Engineering) | ISSN: 2488-9849

Journal DOI: 10.46654/ij.24889849

Vol. 6, Issue 12 (December, 2020) | www.ijaar.org

Article DOI: 10.46654/ij.24889849.e61215

\title{
GEOTECHNICAL ASPECTS OF BREAKWATER DESIGN AND CONSTRUCTION: A REVIEW
}

\author{
Ogbuchukwu, P.O., Okeke, O.C, Urom, O.O., Usen, O. S. and Agoha, C.D. \\ Department of Geology, \\ Federal University of Technology, Owerri, Nigeria. \\ Corresponding author's E-mail: pattsy425@gmail.com.
}

\begin{abstract}
Breakwaters are coastal structures constructed to provide shelter for ships, protect shipping facilities (harbours and ports) from effects of wave action and contribute to reduction/prevention of sedimentation in harbours. Other structures that contribute in mitigation of coastal environmental problems include jetties, groins, seawalls bulkheads laws and revetments. Dredging of harbours and navigational channels are also periodically undertaken to remove sediments deposited in these facilities. The three common types of breakwaters are: rubblemound breakwater, vertical wall or caisson breakwater and floating breakwater. Geotechnical aspects of breakwater design and construction refer to use of geotechnical principles (soil mechanics and rock mechanics) in the design and use of geotechnical/geological materials in the construction of breakwaters. Some of these geotechnical/geological materials that constitute the construction materials include: crushed rocks, soils, concrete synthetic/filter/fibers (plastics) blast furnace slag and coating systems (coaltar, epoxy resin and vinyls). Other engineering principles that contribute to breakwater design and construction include: coastal engineering, environmental engineering and construction engineering. Examples of coastal environmental problems such as flooding in Lagos, Nigeria (Victoria Island) and beach/cliff erosion in California, (USA) Cesot are highlighted. Examples of successfully completed breakwater projects include Eko Atlantic Project/Breakwaters, Lagos (to protect Lagos Harbour and settlements in Victoria Island) and Taconite Harbour Breakwater in Minnesota, USA (to protect ore loading dock).
\end{abstract}

Keywords: Breakwaters, Coastal structures, ships, harbour, geotechnical, Lagos. 
Journal DOI: 10.46654/ij.24889849

Vol. 6, Issue 12 (December, 2020) | www.ijaar.org

\section{$1.0 \quad$ INTRODUCTION}

Coastal environmental problems such as coastal/shoreline erosion (or beach erosion, disappearance of beaches /cliffs and barrier islands, flooding of beaches/coastal settlement and sedimentation in harbor and navigation channels lestuaries have led to recession of many economies around the globe (Bird, 1985, Dolan and Goodell, 1986, Williams and Stewart, 1996, Williams et al, 1997, Omar 2017, Carlson and Plummer, 2009, Montgomery, 2003). Figures 1 and 2 show coastal environmental problems of coastal erosion/flooding in California, USA and North Caroline (USA), respectively while Figure 3 shows coastal flooding in Lagos, Nigeria. Engineers have designed and constructed man-made structures including breakwaters, groins, seawalls, jetties, bulkheads and revetments in order to tackle these problems. These man-made engineering structures are collectively called Coastal structures (Minikin, 1952, Van Bendegen 1960; US Army Corps of Engineers, 1975, Whiteneck and Hockney, 1989). Dredging of harbor and navigational channels are also frequently performed to reduce the amount of sediments deposited in the coastal area (coastal sedimentations) as a result of coastal erosion/shore drift (Shankland, 1949, Chandola 2001; Carlson and Plummer, 2009). 
Journal DOI: 10.46654/ij.24889849

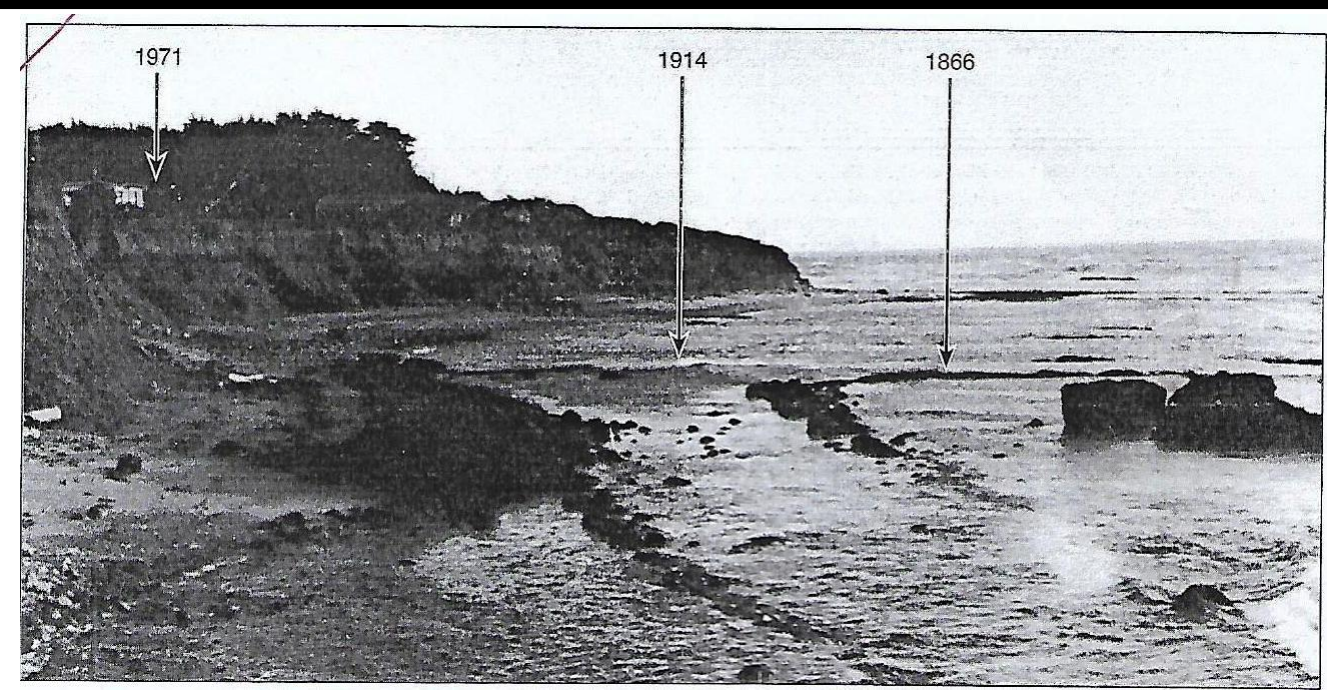

Figure 1: Building, threaded by Cliff Erosion in California, USA (Montgomary, 2003).

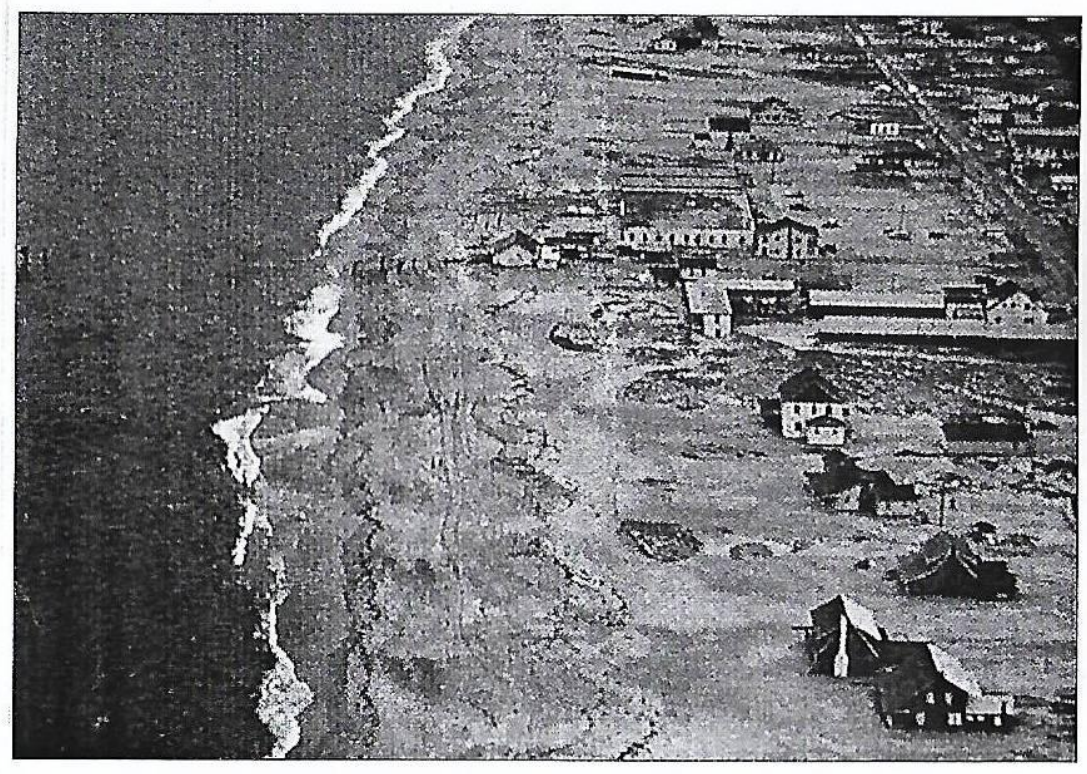

Figure 2: Consequences of storm surges at North Carolina, Outer Banks USA (Montgomary, 2003). 

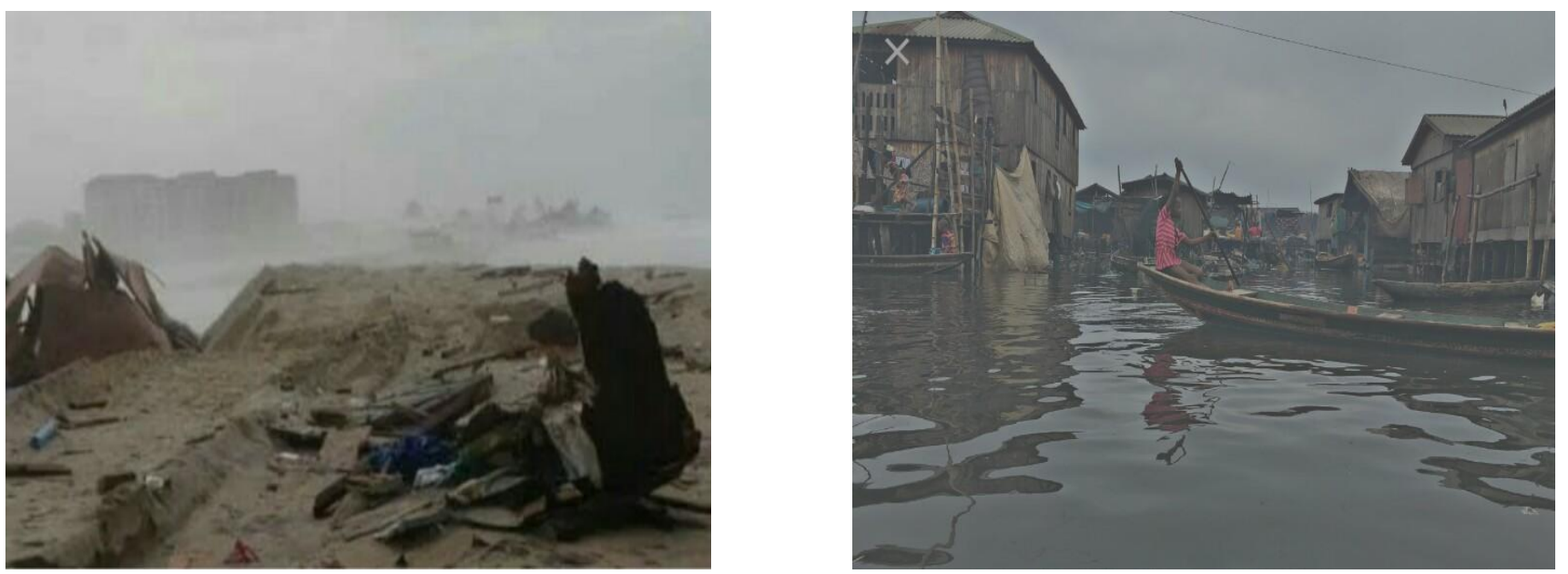

Figure 3: Effects of storm surge in Kuramo and Victoria Island, Lagos, Nigeria (Omar, 2017).

Breakwaters are structures constructed to break up and disperse the waves of heavy seas or oceans and provide shelter/protection for ships, harbours/ shipping facilities, shorelines and generally contribute to increase in shipping activities (Krynine and Judd, 1957; Whiteneck and Hochney, 1989; Moutgomery, 2003). Figures 4 and 5 are typical examples of breakwaters in operation (Krynine and Judd, 1957). Breakwaters though primarily constructed to moderate wave action may also cause sediment redistribution like groins (Montgomery, 2003). Table 1 is definition of terms in relation to breakwater coastal structure and coastal/ocean environment. Breakwater and grains also help to reduce the amount sediments and frequency of dredging in habours. Breakwaters are earth structure, (or rock structures), that is, engineering structures constructed with earthen materials (mostly crushed rock, soils, concrete, fly, ash and bituminous materials) in coastal area. Their design and construction are therefore primarily within the practices of geotechnics (geotechnology or geotechnical engineering). 


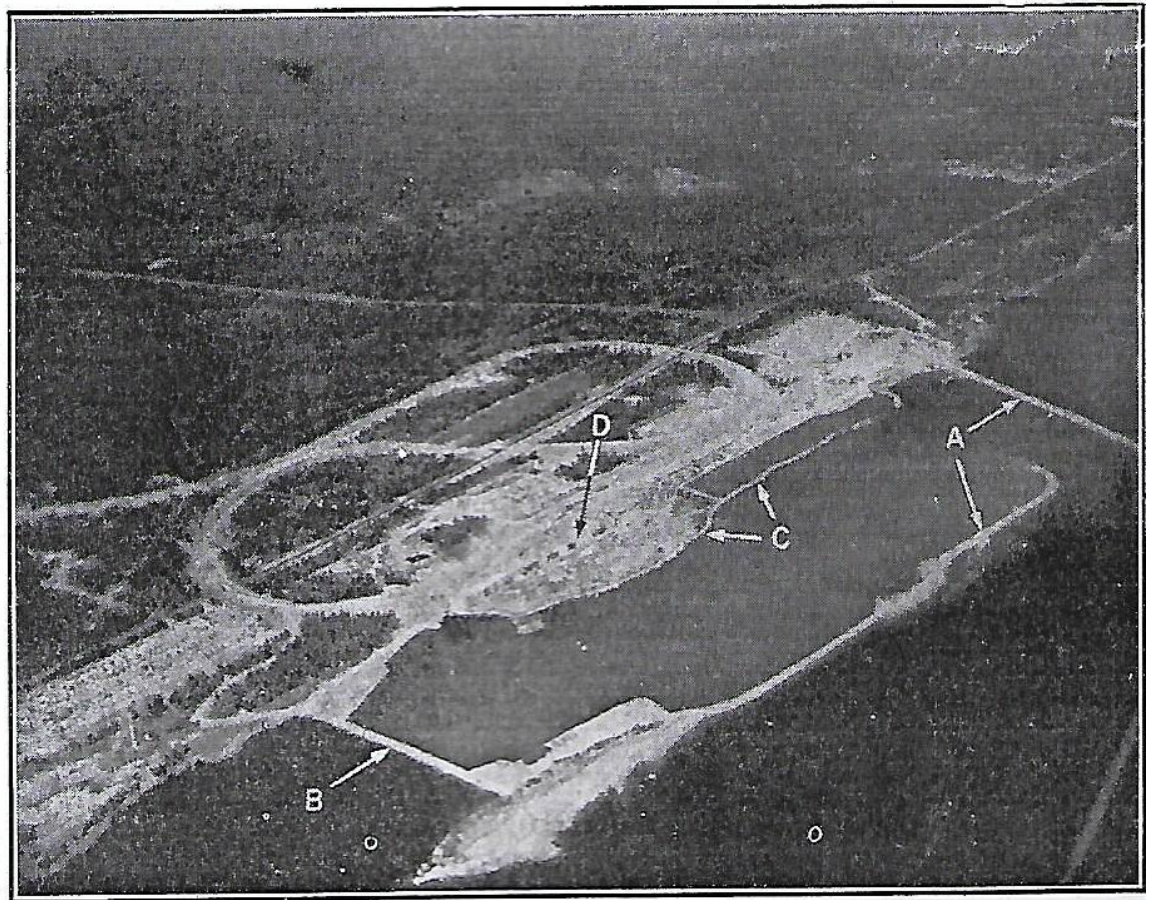

Figure 4: Taconite Habour Breakwater, Minnesto, USA (Krynine and Judd, 1957)

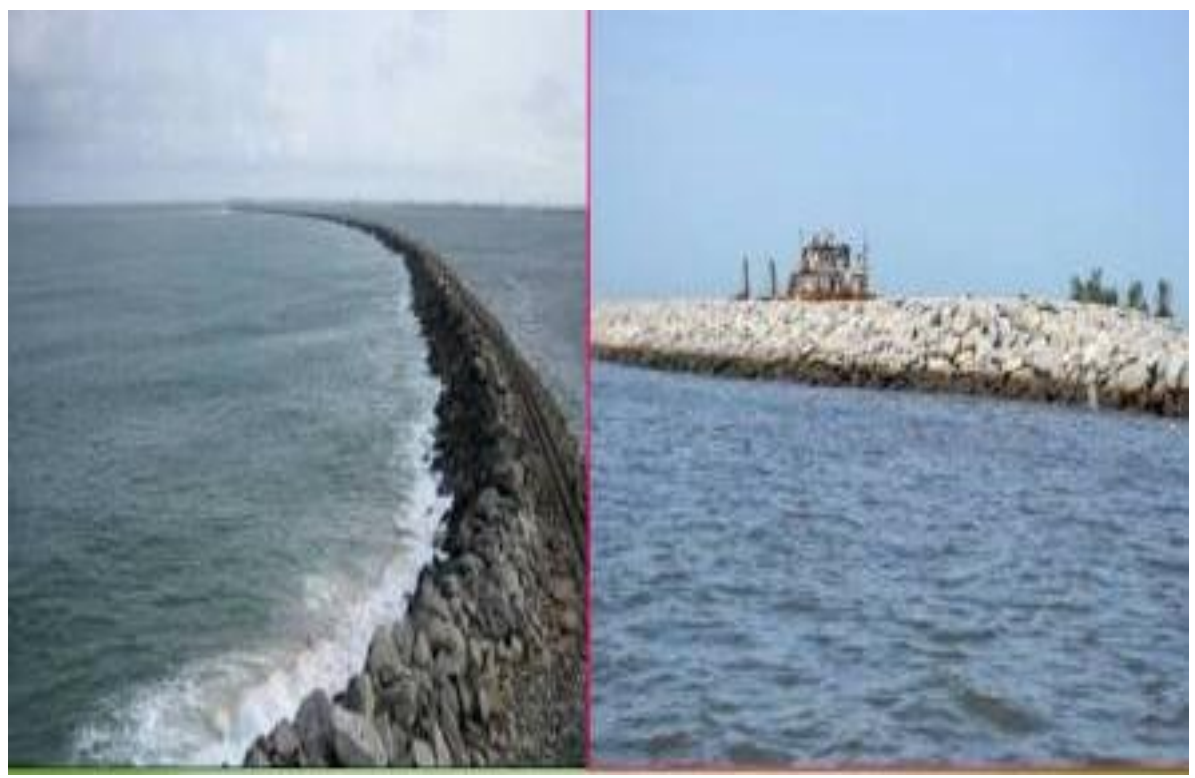

Figure 5: East and West mole breakwaters, Lagos Nigeria (Omar, 2017). 


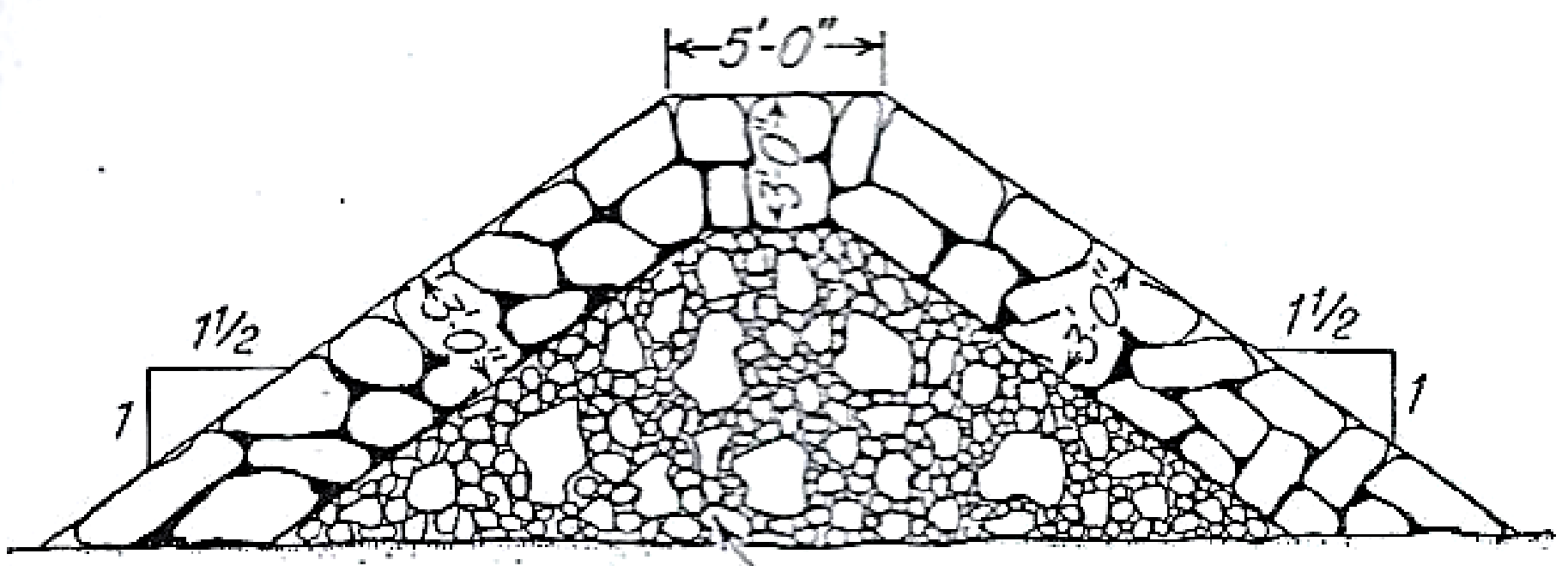

Figure 6: Cross section of typical breakwater (Krynine and Judd, 1957)

Roberts (1981) defined geotechnics as "applied geology in the context of engineering". It deals with engineering in earth materials and three allied fields of engineering geology, mining engineering and aspects of civil engineering concerning earth works, foundations and tunneling constitute the field of study and engineering science of geotechnics, (geotechnology or geotechnical engineering) (Krumbein ,1950; Glossop, 1968; Pilkey, 1989; Coduto, 1999; Okeke and Akaolisa, 2004).

Breakwaters are constructed in the coastal areas primarily to control/mitigate environmental problems in the coastal area (beak erosion and sedimentations, flooding of beaches/coastal settlements and impacts of sea waves on ships/shipping facilities). Other engineering disciplines that influence design and construction of breakwaters include coastal engineering, environmental engineering and construction engineering (US Army Corps of Engineers 1977 and 1978; Moffat and Nichol Engineers, 1981, Mechemehl et al., 1975, Minikin, 1950). The four engineering disciplines, namely; geotechnical engineering coastal engineering environmental engineering (aspect of hydraulic engineering) and construction engineering are therefore interrelated when it comes to design and construction of breakwater in coastal areas.

According to Nagi (2013) and Wiagal (1962), the purpose of construction of breakwaters in coastal areas includes:

i) To shield the harbor from the effects of wave action;

ii) To provide a safe suitable accommodation for ship refuge, supplies and transfer of cargo;

iii) To reduce the amount of dredging in front of an harbor entrance.

iv) To reduce sedimentation of silts and sands in harbor and navigation channels, and 
v) To reduce coastal erosion.

Depending on purpose and type of breakwater, the major materials used in the construction are:

(i) Crushed rock;

(ii) Concrete;

(iii) Soils (clays and sands);

(iv) Industrial wastes (blast furnace slog and fly ash);

(v) Steel sheet piles; and

(vi) Synthetic files (geotechnical, plastic, filter in cloth)

These materials are usually coated with coal, epoxy or vinyls.

Fig. 6 shows cross section of a typical breakwater (Krynine and Judd, 1957).

In this paper, the types of breakwater, and geotechnical aspects of their design and construction are reviewed. Case history of breakwater construction in Lagos Nigeria to protect ships, harbor, beaches and human settlements is also highlighted. The protected beaches have contributed to enhancement of human activities of shipping, fishing, filling and recreation.

Table 1: Definition of terms in relation to breakwaters coastal structures and coastal environment.

1. Breakwater: Structure constructed to protect shore area including beaches ships and harbours from effects of sea/ ocean waves.

2. Jetty: In open seacoast jetty is a structure extending into the body of the water and designed to protect entrances to rivers, bays and harbours from sediments of littoral drift.

3. Seawall and bulkhead: They are protective water-front structures often built to separate land and water areas. They are designed to prevent erosion and other damage due to wave actions. They may also serve for docking of vessels. Seawall may range from a single riprap deposit along the stretch of a shore to a regular masonry retaining wall. Bulkheads are vertical walls either of timber boards or steel-sheet piling driven into the ground vertically and anchored to the natural ground behind the wall.

4. Revetment: a facing of stone or concrete built to protect impoundment or stone structure against erosion by wave action or current.

5. Groin: A shore protection structure built usually perpendicular to the shore line to trap littoral drift or retard erosion of the shore. 
6. Coast: A strip of land of indefinite width (may extend several kilometers) that extends from the shoreline inland to the first major change in terrain features.

7. Shore: The narrow strip of land in immediate contact with the sea/ocean including the zone between the high and low water lines. A shore of unconsolidated materials is usually called a beach.

8. Beach: The zone of unconsolidated material that extends land ward from low water line to a pleasure where there is marked change in material or line of permanent vegetation.

9. Shoreline/benchline/coastline: An interaction of specified plane of water with the shore, beach or coast. There was the low water of shoreline high war structure or mean-water shoreline (or mean seas level (in nautical ocean survey charts).

10. Cliff: A high stiff face rock coastal areas that consist of rocky terrain (instead of unconsolidated terrain of beach in other words).

11. Coastal Area: The land and sea area bordering the shoreline, in other words coastal areas consists of beaches and cliffs.

12. Beach/Costal Erosion: The carrying away of beach materials by wave action, tidal currents, littoral currents or wind.

13. Wharf/Quay: A structure built on the shore of a habour, river or canal so that vessel can lie along to receive and discharge cargo and passengers.

14. Harbour and Port: Any potential water area affording place of safety for vessels. Port is a place where vessels (ships) can transfer cargo and people. It may be the entire harbor including its approach and anchorages or it may be the commercial part of a harbour where quays/wharfs docks, and repair shops are situated.

15. Dock: Dock is a maritime structure in the shore where vessels (ships) may be berthed (anchored) for repairs (dry dock or to facilitate loading and unloading of passengers and cargo (net dock).

16. Barrier Island: Long, low, narrow, Islands parallel to coastal line that protects the coastline from wave action.

17. Basin: A naturally or artificially enclosed or nearly enclosed harbor area for small craft.

18. Littoral Drift/ Longshore drift: The sedimentary material moved in the literal zone under the influence of waves and currents.

19. Geotextile/Geotextile Filter: Geotextile is any permeable materials used with foundation soils, rock or any other geotechnical material as an integral part of man-made project or structure. geotextile filter is any permeable fabric of synthetic fibers whose function is to retain soil and be permeable to water. 
20. Pier: A structure usually of open construction extending out into the water from the shore to serve as a landing place, a recreational facility etc rather than to afford coastal protection

21. Lagoon: A semi enclosed quiet body of water between a barrier island and the mainland Example, Lagos Lagoon.

22. Tides: Tides are the periodic regional rise and fall of water levels as a consequences of the effects of the gravitational and pull of the sun and moon, on the watery envelope of ocean surrounding the earth. Thus we have low tide (low sea level) and high tide (high sea level) and therefore mean or average sea level in the shoreline or coastline.

Table 2: Some performing breakwaters and their locations

\begin{tabular}{|c|c|c|c|}
\hline $\mathbf{S} / \mathbf{N}$ & Name of Breakwater & Location & Reference \\
\hline 1 & $\begin{array}{l}\text { Lagos Harbour Breakwater (East and West } \\
\text { Moles) }\end{array}$ & Lagos Nigeria & Omar, 2017 \\
\hline 2 & $\begin{array}{l}\text { Eko Atlantic Dream City Project/Breakwater } \\
\text { (Victory Island) }\end{array}$ & Lagos Nigeria & Omar, 2017 \\
\hline 3 & Zeebruggen Harbour Breakwater & Belgium & Krynine and Judd, 1957 \\
\hline 4 & Taconite Harbour Breakwater & Minnesote, USA & Krynine and Judd, 1957 \\
\hline 5 & Oregon Shore Breakwater & Oregon, USA & Mongomery, 2003 \\
\hline 6 & Cleve land Harbour Breakwater Cleveland & Ohio, USA & $\begin{array}{l}\text { U.S Army Corps of } \\
\text { Engineers } 1977\end{array}$ \\
\hline 7 & Crescent City Breakwater & California, USA & $\begin{array}{l}\text { US Army Coprs of } \\
\text { Engineers, } 1977\end{array}$ \\
\hline 8 & Santa Cruz Breakwater & California, USA & $\begin{array}{l}\text { US Army Corps of } \\
\text { Engineers } 1977\end{array}$ \\
\hline 9 & Rincon Island Breakwater & California & $\begin{array}{l}\text { US Army Corps of } \\
\text { Engineer } 1977\end{array}$ \\
\hline 10 & Kaluhui Breakwater & Hawaii & $\begin{array}{l}\text { US Army Corps of } \\
\text { Engineers } 1977\end{array}$ \\
\hline 11 & Baie_Comeau Breakwater & Quebec, Canada & Jarlan, 1961 \\
\hline 12 & Diablo Canyon Breakwater & California, USA & $\begin{array}{l}\text { US Army Corps of } \\
\text { Engineer, } 1977\end{array}$ \\
\hline
\end{tabular}

\subsection{TYPES OF BREAKWATERS}

The three common types of breakwaters are Rubble-mound breakwaters, vertical wall or caisson breakwater and floating breakwater (Krynine and Judd, 1957; Jarlan, 1961; US Army Corps of Engineers; 1977; Moffat and Nickal Engineers, 1981). These are discussed below;

\subsection{Rubble-Mound Breakwater.}

This type of breakwater is the most common breakwater used to protect shoreline and harbours and navigation channels against wave action and sediment transportation. It consists of several 
armor layers with different densities. A mound is an artificial embankment or ridge composed of heavy units of assigned size which may be built by dumping material from the sea bottom or bringing material from other location while rubble is irregularly shaped, rough units, ranging in sized up to $30 \mathrm{~m}^{3}$ each and up to nearly 90 tons each in weight. This type of breakwater simply consists of large heaps of loose elements, such as gravel and quarry stone or concrete blocks and the small size rock is covered with heavy rock or concrete elements. The outer layer is called the armour layer (Nagi, 2013). Rubble mound breakwaters use structural voids to dissipate the wave energy. Rock or concrete armour units on the outside of the structure absorb most of the energy, while gravels or sands prevent the wave energy's continuing through the breakwater core. Rubble mound breakwaters are also used for protection of harbor and beaches against wave action and protection of navigation channels and beach against sediment transportation. Hard rock, which is more desirable, usually consists of either granite or traprock (fine-grained igneous rock). Limestone, dolomite, and sandstone are undesirable because of their lesser hardness, toughness, and durability. The diagram below shows the component of a typical Rubble mound breakwater (Figure 9, 10 and 11).

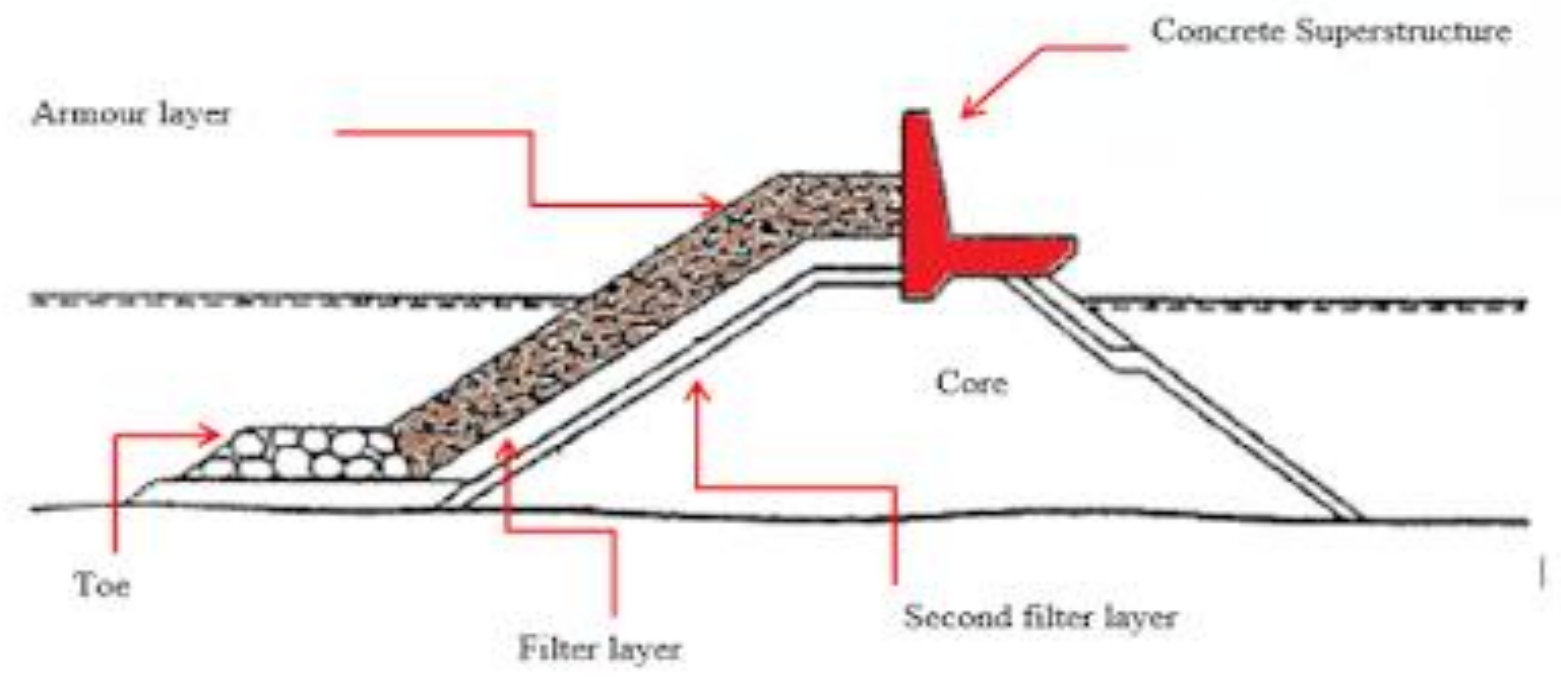

Figure 7: Component of rubble mound breakwater (US Army Corps of Engineers, 1977)

Core -The purpose of the core is to prevent wave transmission into harbour; hence the core material is not too coarse. It is normally clay or clays and mixture.

Toe -The Toe functions as the foundation for the armour layer. It also may catch armour units displaced from armour layer; The Toe is normally constructed of large stones of quarry run or the most coarse filter layer.

Filter layer -The objective of the filter layer (under layer) is to prevent the core material from being washed out through armour layer. It is built of quarry run or synthetic materials. 
Journal DOI: 10.46654/ij.24889849

Vol. 6, Issue 12 (December, 2020) | www.ijaar.org

Article DOI: 10.46654/ij.24889849.e61215

Armour layer - The purpose of armour layer is to protect the core from direct wave attacks by the dissipation of wave energy. Armour layers are built of large rocks or larger concrete armour units.

Superstructure -The superstructure is used either in order to reduce the crest elevation or to reduce wave overtopping, or as a roadway for traffic or pipelines. The superstructure is usually constructed of concrete.

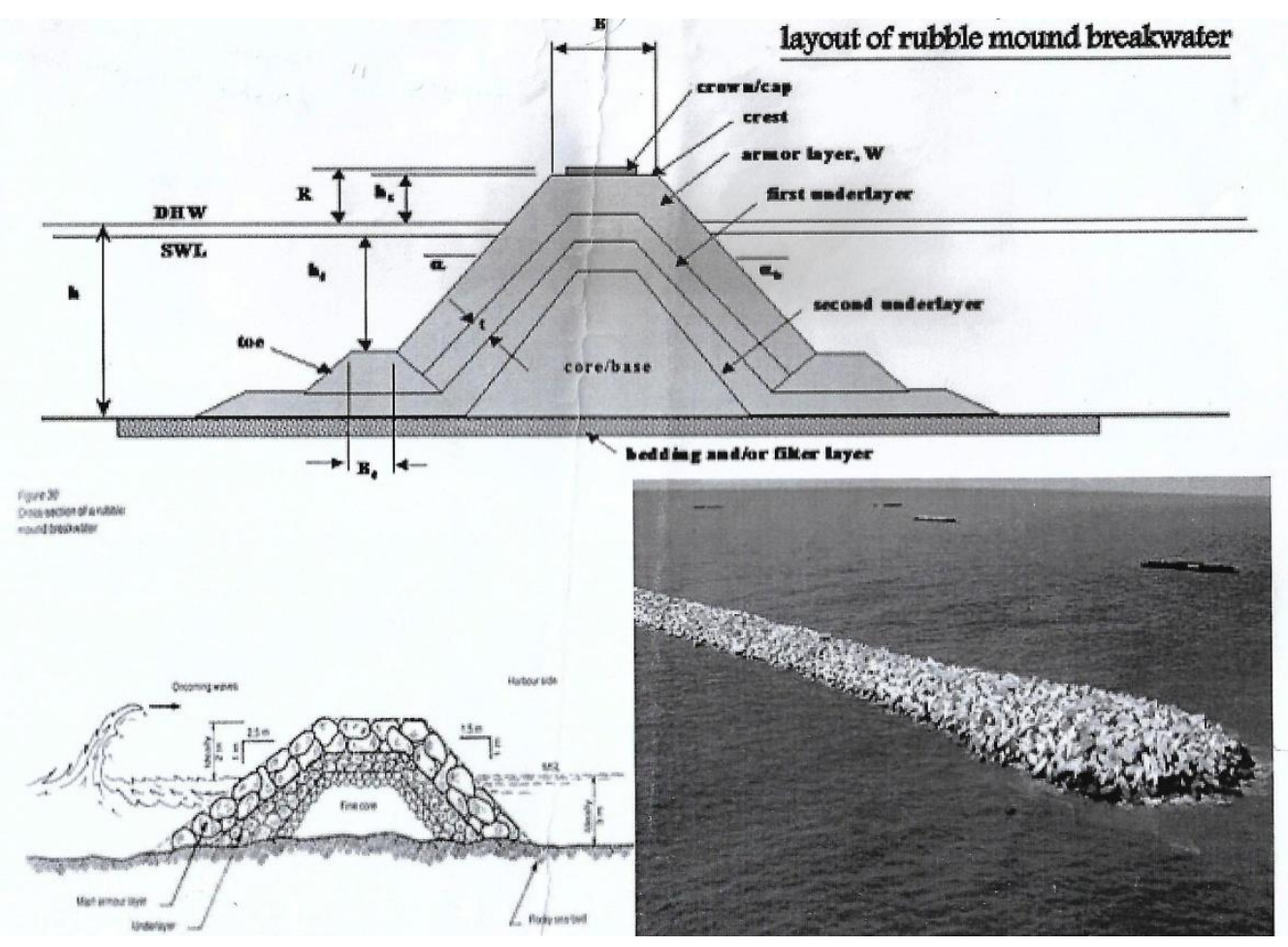

Figure 8: Layout of rubble mound breakwater (Wikipedia/Google Images) 


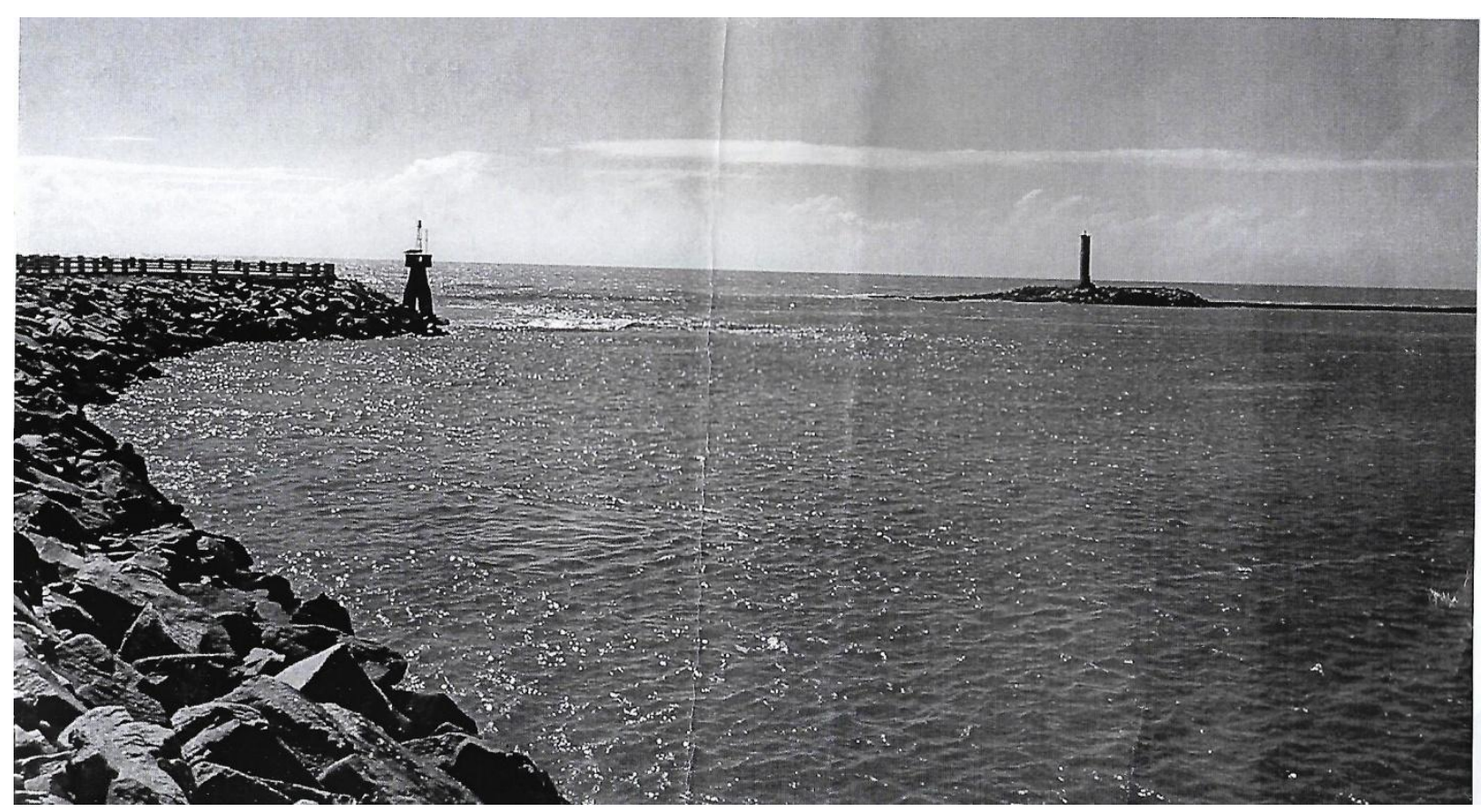

Figure 9: Field view of rubble mound breakwater (Wikipedia/Google Images)

\subsection{Vertical wall or caisson Breakwaters}

A typically caisson breakwater have vertical sides and are usually erected where it is desirable to berth one or more vessels on the inner face of the breakwater. They use the mass of the caisson and the fill within it to resist the overturning forces applied by waves hitting them.

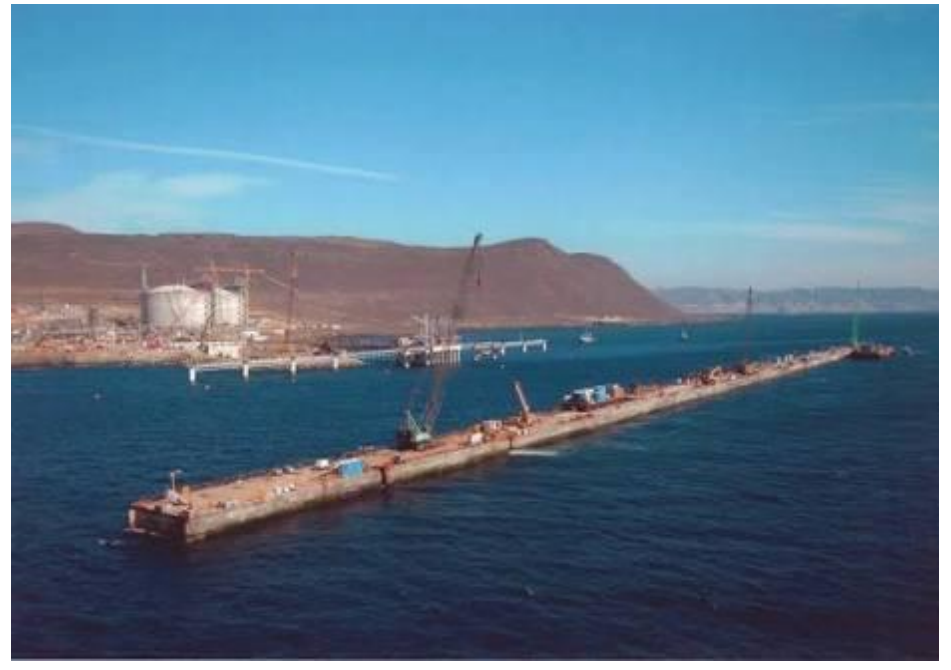




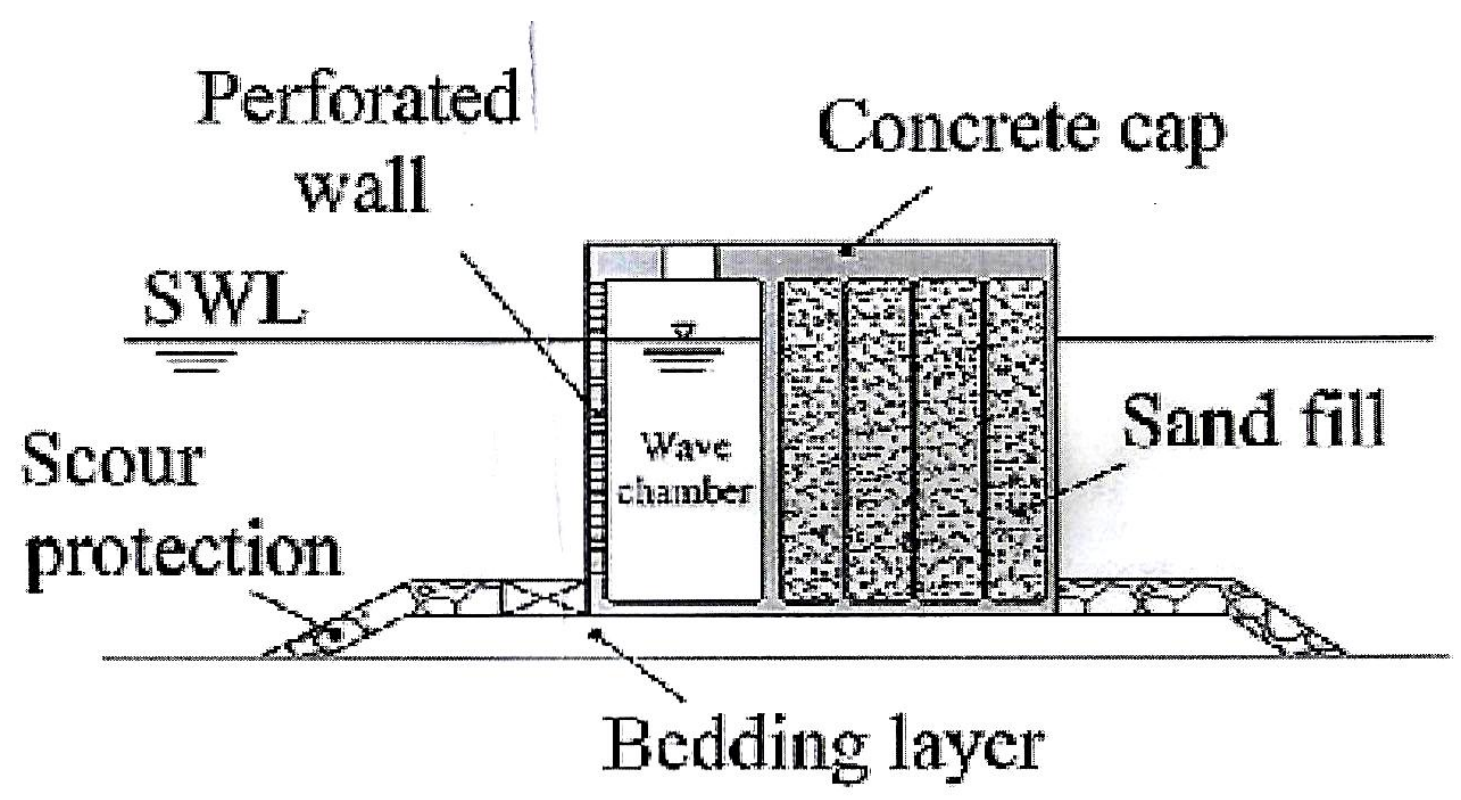

Figure 10: Cross Section of Perforated Wall Breakwater (Wikipedia/Google Images).

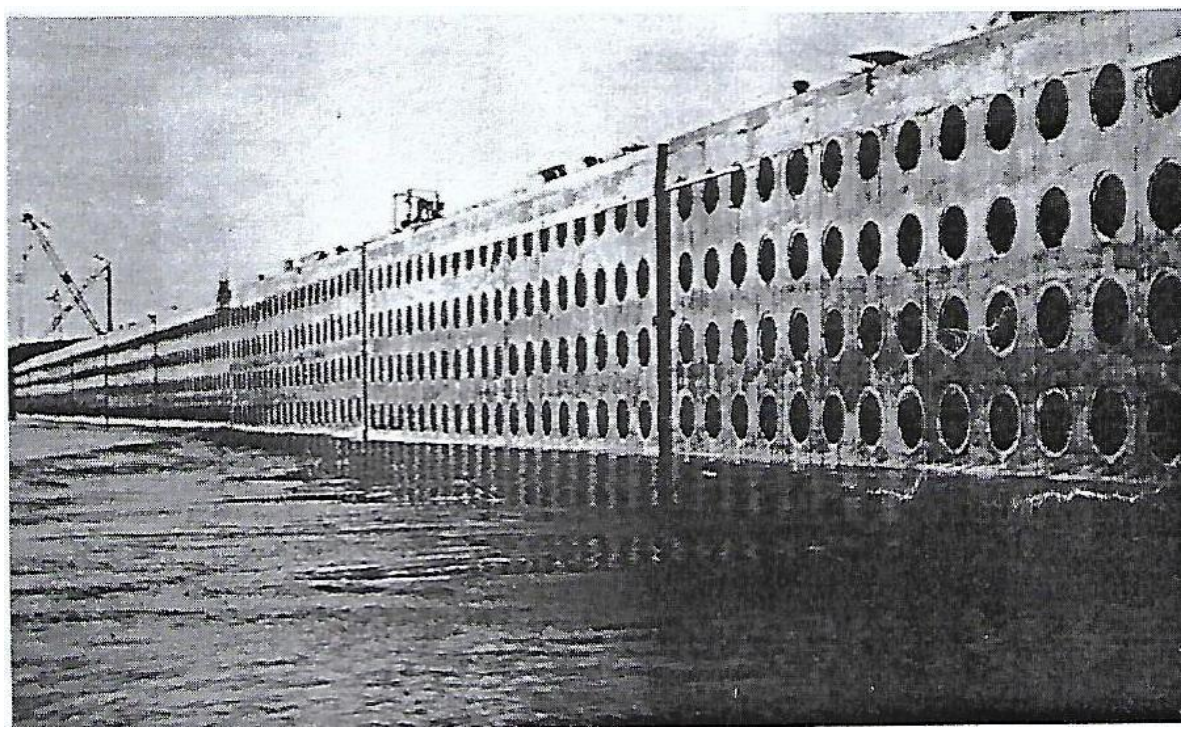

Figure 11: Perforated Caisson Breakwater, Quebec, Canada (Whiteneck and Hockney, 1989).

\subsection{Floating Breakwaters}

To be effective as a breakwater, the motions of a floating structure must be of small amplitude so that the structure does not generate waves into the protected harbor side. This type of breakwater is applied for boat basin protection, boat ramp protection and shoreline erosion control. 

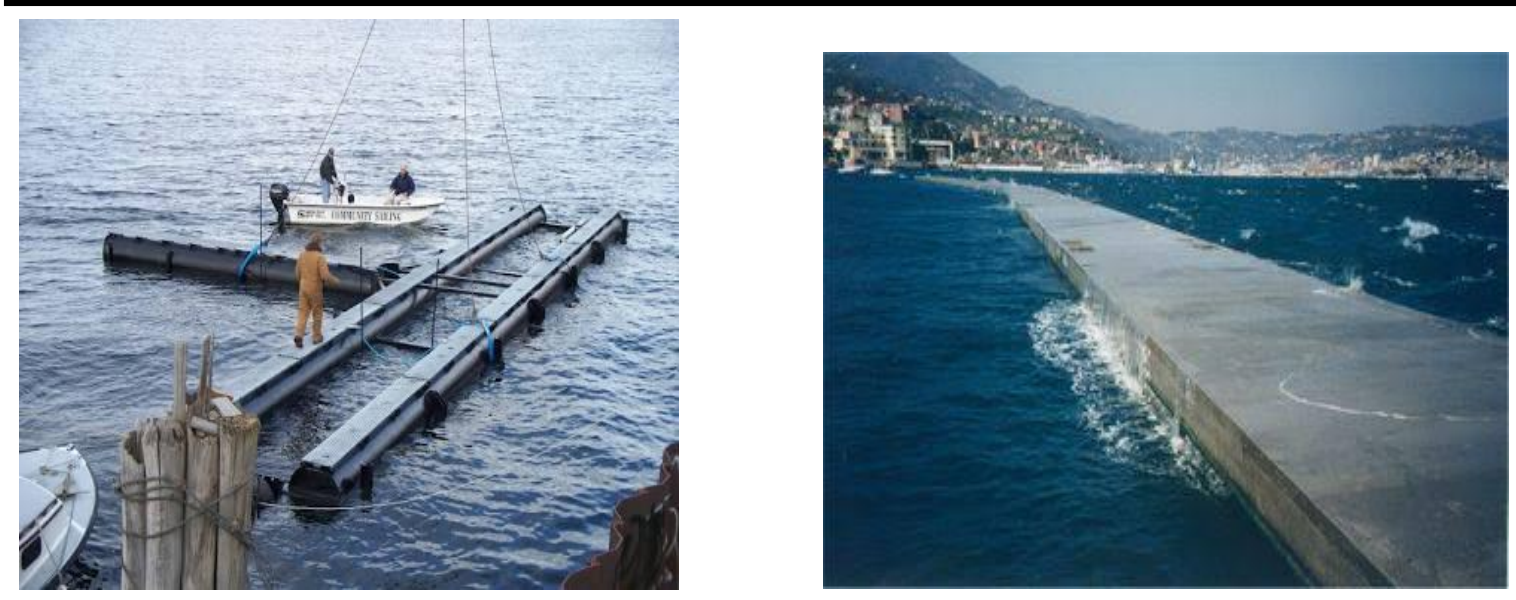

Figure 12: Floating breakwater (Moffat and Nichol Engineers 1981)

\subsection{PRINCIPLES AND PRACTICES OF BREAKWATER DESIGN AND CONSTRUCTION}

\subsection{Design stages}

During the design and construction practices of breakwater, certain design stages are recognized in some countries which are related to the general conditions of contract between employer and consultant. The design stages include project definition stage, feasibility design stage, preliminary design stage and detailed engineering stage.

\section{i. Project definition stage}

Every projects most start with need, requirements or lacks (project definition stage). This project definition stage defines this requirement or need by setting project objectives which will present requirements and restrictions. The project objectives stated will help in establishing the appropriate engineering solution to meet the identified need or lack.

\section{ii. Feasibility design stage}

The feasibility stage means the review of the system with respect to technical, economic, social and environmental consequences and feasibility. The main activities at this stage are the identification of the functions, constraints and information requirements that will enable the design to go forward. Geotechnics investigation for the project is also performed at this stage.

\section{iii. Preliminary design stage}

Preliminary design means giving shape to the system, that is when many of the investigations and study activities must be carried out and the investigations include; determination of wave climate or current regime, environmental assessments and economical analysis. This has to be an interactive process, involving many parties, to gain agreement and select a preferred solution. 


\section{iv. Detailed design stage}

Once the various criteria have been satisfied, detailed design must involve the development of all structural elements, using further in situ investigation and physical and technical data, to produce drawings, specifications and bill of quantities.

During the working design phase further design modification may be necessary as a result of onsite difficulties such as unforeseen ground conditions or changes in working approaches. When this is encounter, the designer should ensure that the original design concepts are fully understood and the design changes do not compromise any other aspect of structure performance.

In the operational period the continued performance of the structure is ensured by setting a monitoring and maintenance programme.

\subsection{Applicable Engineering Principles and Practices}

\subsubsection{Geotechnical Engineering Principles and practices}

i. Physical condition aspects which should include; Ground conditions (geotechnical),Topographic and bathymetric conditions, Hydraulic forces - waves, currents, water levels, Morphological changes, Sediment load and movement, Uncertainties of physical conditions (confidence limits).

ii. Technical data aspect which should include; Material properties (e.g. rock density, quality, durability and availability), Accuracy of design information, including analytical methods used, Structure-specific design methods and Nature of failure (progressive or instantaneous, complete or partial).

iii. Construction aspect which should include; Ability to build the structure, Contractor experience and resources, Health and safety issues, Conditions during construction (e.g. storm or flood frequency and magnitude), Access of construction plant, Material quality, Alternative material availability (sources) and Site area for storage of materials and operations.

iv. Maintenance aspects which include; Characteristics of structure response, Frequency and type of intervention, Availability of suitable resources for repair (materials, plant, expertise), Funding and Accessibility for construction plant.

\subsubsection{Coastal Engineering Principles and Practices}

Coastal engineering involves developing and protecting existing coastal protection work with the view to predict future natural coastal processes. French (1997) postulate that the major civil aspects of coastal engineering is coastal protection and management which can be achieved through the formation of framework for projects to be planned, investigated and implemented to meet the needs of the environment and its people. The Coastal engineering processes such as 
modeling is used to estimate the changes on environment and angle of repose of shorelines, site investigation to study the cycles of hydrographic and marine life status, as well as processing these to build a profile for the shorelines on which breakwaters are constructed. For example, Iskander (2007) studied and developed a monitoring model for studying coastal structure along the El Agami area of Egypt. They noted that where breakwaters exist, shoreline fluctuates, marine life is impacted and also wave hydraulics. Coastal engineers need to record and study the gradual change that takes place due to the presence of breakwaters. Issues concerning wave distribution, shoreline sand composition, coastal calibration, marine survey and effect on the hardours' population are taken into account. Apart from these, breakwaters also affect the coastal structure such as villages, ports and other human activities (Iskander, 2007).

Furthermore, coastal engineers also need to ensure that the construction of breakwaters and estuaries does not adversely affect human activities as a result of design fault of these structures. Donnel, (2006) attributed that the breakwaters on Tedious Creek estuary on the shoreline of Chesapeake Bay in Dorchester County, MD caused substantial damage to local vessels than the benefits it provided for its shelters. Similarly, breakwaters can also result in beach morphology that effectively negates the protection objective when breakwaters are constructed with limited knowledge applied relating to practical engineering. Therefore, coastal engineers are responsible for studying the wave conditions, down drift side, expected erosion and current patterns behind submerged breakwater, to gauge incident waves. These mechanisms, according to Ranasinghe \& Sato (2007), can relatively influence the function and utility of breakwaters' function. Thus, coastal engineering is greatly influenced by the type and design of breakwaters structures. In general, knowledge of the coastal condition helps professionals in the field to construct, facilitate and execute better breakwater construction. Breakwater construction is a field that is directly related with coastal engineering.

\subsubsection{Construction Engineering Principles and Practices}

Breakwaters and such coastal structure construction combine design and functionality with the view to protect the coastal area. The design process is similar to structural design of buildings as it entails paying attention to functional requirements, limitations of the state of the structure, exposure, construction phases and occurrence of natural conditions. Breakwaters also require considerations for knowledge of construction materials including quarry stone. Based on Moffett and Nichol Engineers (1981), coastal structures like breakwaters and jetties are influenced by long periods of water level changes. They need to be built parallel to the entrances, in an attempt to stabilise entrances and safe navigation. Knowledge of construction material is very important for choosing and designing breakwaters to complement the need of the local landscape and environment. Arena \&Filianati (2007) attributes that breakwaters are made up of rubble mounds or caissons or are concrete filled, knowledge of construction material adds to the skills required for developing structures for dispersing wave currents to minimise impact and conserve energy from wave hydraulics where possible. Also, new construction material knowledge provides an edge over the design and planning of the breakwater armour unit.

Furthermore, coastal protection design and construction require development and use of probabilistic design tools to gauge uncertainties, prediction of wave impact, as well as structure 
stability. The main concerns for construction engineers are that the structures can sustain its functionality for coastal protection, regardless of the wave conditions and transformations of water bodies. It requires construction engineers to have knowledge of coastal shores by using prediction models for wave transformation to study the effect of wave height, setup and distribution before designing the breakwater and jetty structures.

\subsubsection{Environment Engineering Principles and Practices}

Breakwaters structures are one of the engineering solutions to resolve the problem of erosion and sedimentation of shorelines. These are constructed with the view to sustain the shoreline and benefit the local human communities. These engineering structures affect the hydraulic system of the areas and also produce long and short term impacts on marine life. Hydrodynamic conditions, sedimentation patterns, wave motion, physical and chemical factors tend to alter the composition and nature of the habitat. The habitat also tends to change in its characteristics and life cycle due to the change induced by the presence of breakwaters. The construction of breakwaters for creating inlets often results in floral and faunal morphology of marine life due to the quality of sand, water chemical properties and the wave action. For this purpose, marine engineering knowledge, combined with the breakwater development know how, can help local engineers to establish dynamic coastal structures to fit within the parameters of the natural environment.

\subsection{GEOTECHNICAL ASPECTS OF BREAKWATER DESIGN CONSTRUCTION}

AND

\subsection{Geotechnical Investigation of the Soil/Sea bed}

\subsubsection{General Introduction}

The geotechnical investigation of the sea bed/soil is used to determine the type of founding material and its extent. The construction of breakwaters takes place along shores and river mouths with a great variety of subsoil conditions. Bedrock underlies these layers at various depths. The results of this investigation will have a direct bearing on the type of cross-section of the breakwater. It is essential to determine what the coastline consists of, whether is a soft or hard rock (like coral reefs or granite), sand (as found on beaches), clay (as in some mangrove areas); and soft to very soft clay, silt or mud (as found along some river banks, mangroves and other tidal areas) so as to know what may be encountered during the construction. In several deltaic regions, layers of peat may also be present. These soil layers form the foundation bed for the structure and need to withstand groundwater flow, wave loads and differential water pressures. During the construction of breakwaters, they are the sub-base for vehicles and equipment driving across the site. When submerged, they will be exposed to eroding currents and waves.

Therefore, a thorough knowledge of the soil types present, including their characteristics and the stratification is a prerequisite for the design and execution of breakwater construction and closure operation. 
Geotechnical data can be obtained from sample-borings analyzed in laboratories and penetrometer-tests executed in the field. The number of borings is usually limited in relation to the area considered and to obtain a reasonable picture of the sub-bottom, an overall examination, together with historical and geological information, is required. Particularly in deltaic areas and tidal inlets, former gullies filled up with different types of soil may give sudden changes in the sub-bottom profiles of soil layers.

The most important parameters of the sub-bottom are stratification, soil type and phreatic levels. Laboratory tests on samples of every layer of clayey soil will give the values for cohesion, angle of internal friction, Atterberg limits and water content. Granular soil types are characterized by the grading of the grain sizes, the sharpness (roundness) of the grains and the pore volume (relative density).

Cohesion and friction-angle are the most important parameters for soft soils. The field tests are done by using Standard Penetration Tests (SPT), giving the number of blows needed to hammer a pin down into the ground a predetermined depth or by using the Dutch Cone, which gives the force required to push a cone down into the soil. These values are sometimes translated via relation-tables into values for cohesion and friction-angle. Triaxial testing of soil samples is far more accurate. Triaxial tests can be drained or undrained and consolidated or unconsolidated, which leads to different values for the same soil.

For granular material (sand), the relative density and the permeability are the most important parameters. The grain structure itself is strong enough to withstand considerable surcharges. Problems may arise if some grains want to rearrange to form slightly more dense packing and the pore water cannot escape. The latter is the case if the permeability is low. This applies to sand with a high content of fines. Generally, the $10 \%$ finest part of the sieve curve determines the permeability.

\subsubsection{Basic Geotechnical Investigations}

Basic geotechnical investigations normally suffice for small or artisanal projects, especially when the project site is remote and access poor. A basic geotechnical investigation should be carried out or supervised by an experienced engineer or geologist familiar with the local soil conditions. The following activities may be carried out in a basic investigation using only portable equipment:

i. Retrieval of bottom sediments for laboratory analysis;

ii. Measurement of bottom layer (loose sediment) thickness; and

iii. Approximate estimation of bearing capacity of the sea bed.

The equipment required to carry out the above-mentioned activities consists of a stable floating platform (a single canoe is not stable enough, but two canoes tied together to form a catamaran are excellent), diving equipment, a Van Veen bottom sampler (may be rented from a national or 
university laboratory), a $20 \mathrm{~mm}$ diameter steel pricking rod and a water lance (20 $\mathrm{mm}$ diameter steel pipe connected to a gasoline-powered water pump).

Before the start of any work, the area to be investigated should be marked via a set of marker buoys or a scaffold pipe frame placed on the sea bed and the exact coordinates noted for future reference. To retrieve samples from the sea bed, a Van Veen hand operated bottom sampler is required. Simply picking up samples from the sea bed with a scoop or bucket disturbs the sediment layers with the eventual loss of the finer material and is not a recommended method. The sediments thus collected should then be carefully placed in wide-necked glass jars and taken to a national or university laboratory for analysis. At least $10 \mathrm{~kg}$ of sediment are normally required by the laboratory for a proper analysis.

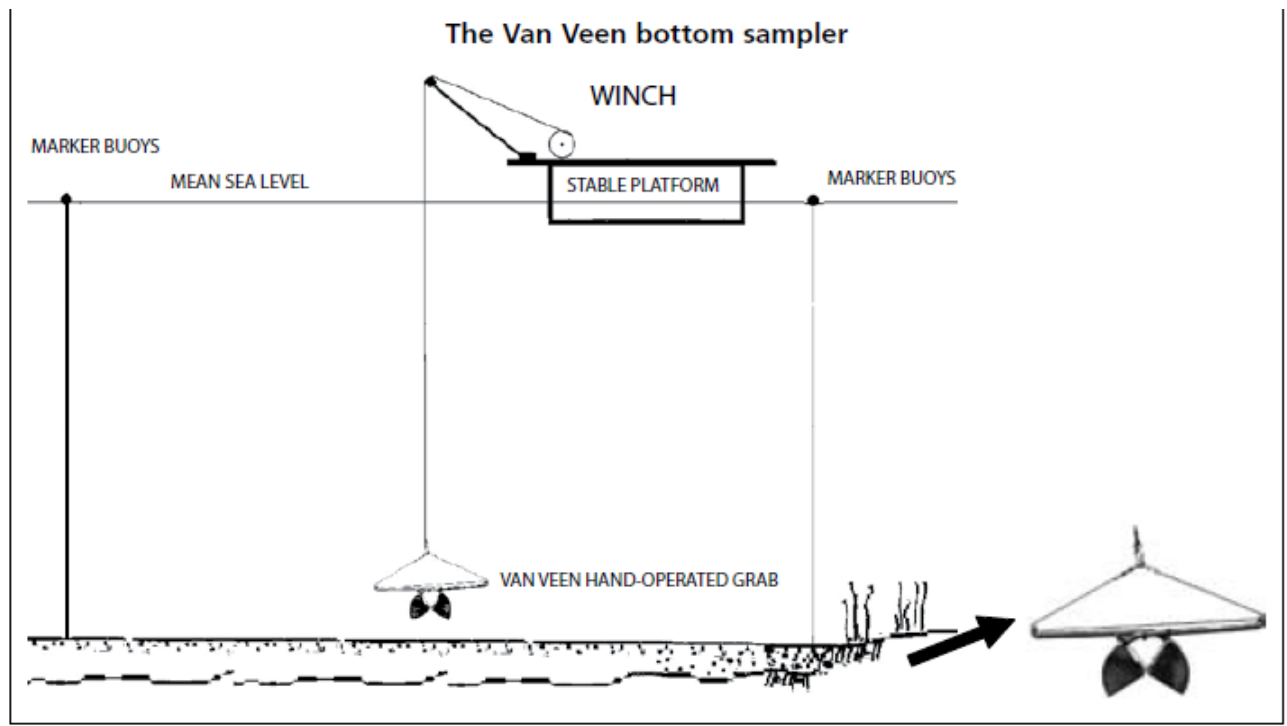

Figure 13: Bottom sampling during soil investigation (Coduto, 1999)

In most cases this layer has to be removed by dredging to expose the harder material underneath. To determine the thickness of this harder layer, a water lance is required. This consists of a length of steel tubing (the poker), sealed at the bottom end with a conical fitting and connected to a length of water hose at the top end. The water hose is connected to a small gasoline-powered water pump drawing seawater from over the side of the platform. The conical end has four $3 \mathrm{~mm}$ diameter holes drilled into it. The diver simply pokes the steel tube into the sediment while water is pumped into it from above until the poker stops penetrating. The diver then measures the penetration. This method is known as pricking which works very well in silty and muddy deposits up to 2 to $3 \mathrm{~m}$ thick but not very effective in very coarse sand with large pebbles. 
Journal DOI: 10.46654/ij.24889849

Vol. 6, Issue 12 (December, 2020) | www.ijaar.org

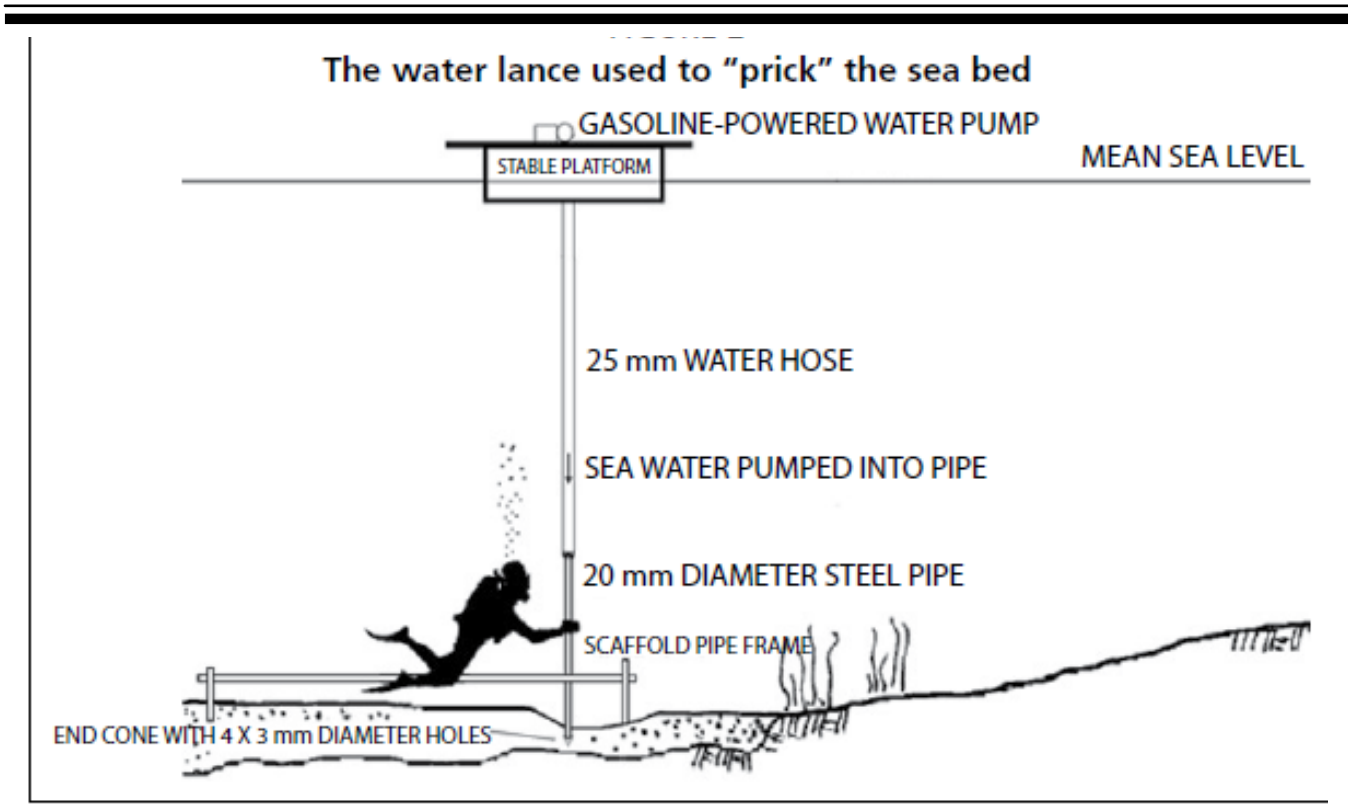

Figure 14: Bottom sampling during soil investigation (Coduto, 1999)

Once the layer of soft sediment has been identified (sampled) and measured (pricked), it is then necessary to determine the hardness of the underlying layer. The underlying layer may be rock, clay or compacted sand. If the layer is rocky, the diver should collect a piece of the material for laboratory analysis using a hammer and chisel. For softer types of material, the diver (with a submerged weight of around 10 kilograms) should use a steel probe $(1 \mathrm{~m}$ long, $12 \mathrm{~mm}$ in diameter) or pocket penetrometer. An area of around $300 \mathrm{~mm}$ square should be cleaned of loose sediment and the probe or penetrometer placed vertically over it. The $10 \mathrm{~kg}$ exertion on the probe will cause the probe to penetrate into the material. The diver then notes the penetration for the engineer to estimate the bearing capacity. If a pocket penetrometer is used, the bearing capacity may be read off the penetrometer scale directly.

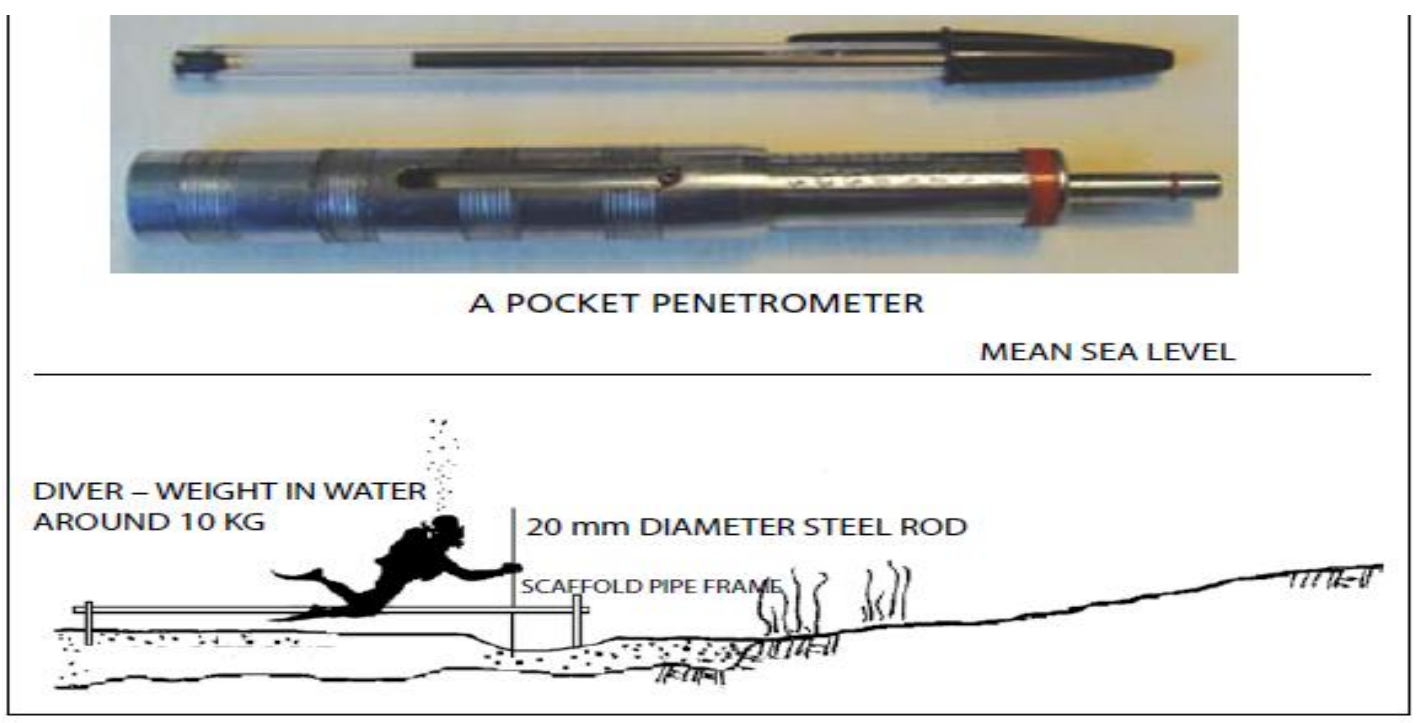

Figure 15: Estimating the bearing capacity of the foundation (Coduto, 1999) 


\subsubsection{Advanced Geotechnical Investigations}

An advanced geotechnical investigation normally requires the retrieval of undisturbed core samples, taken from the level of the sea bed down to a depth ranging from 10 to $30 \mathrm{~m}$ depending on the type of structure envisaged and the ground conditions obtaining at the site.

Advanced geotechnical investigations are normally carried out by specialist contractors or soil laboratories and require a mobile drilling rig. The drilling rig can travel to most destinations but must be installed on a stable platform before it can be used to drill for cores over water.

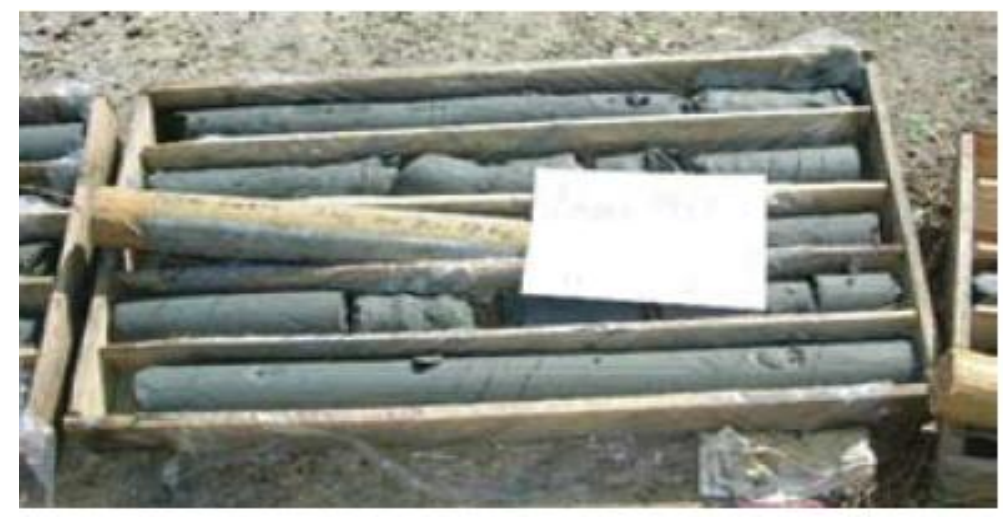

Figure 16: Core samples of hard clay retrieved from 15 metres below sea bed (Coduto, 1999)

\subsubsection{Construction Methods of Breakwater}

There are several types of equipment available for marine construction, both land-based and floating. The high cost of purchase, however, puts most of this equipment beyond the reach of village cooperatives, artisanal contractors and small general-building contractors. Due to this, most of the heavy plant will be made available through the government or public works department or local contractors.

Large specialist marine contractors often use floating equipment (all cranes mounted on barges for example and material like the core is often dumped using barges). When planning the construction of a marine-related project, it would be useful to know beforehand what type and size of construction plant is available in the vicinity of the village or landing. 

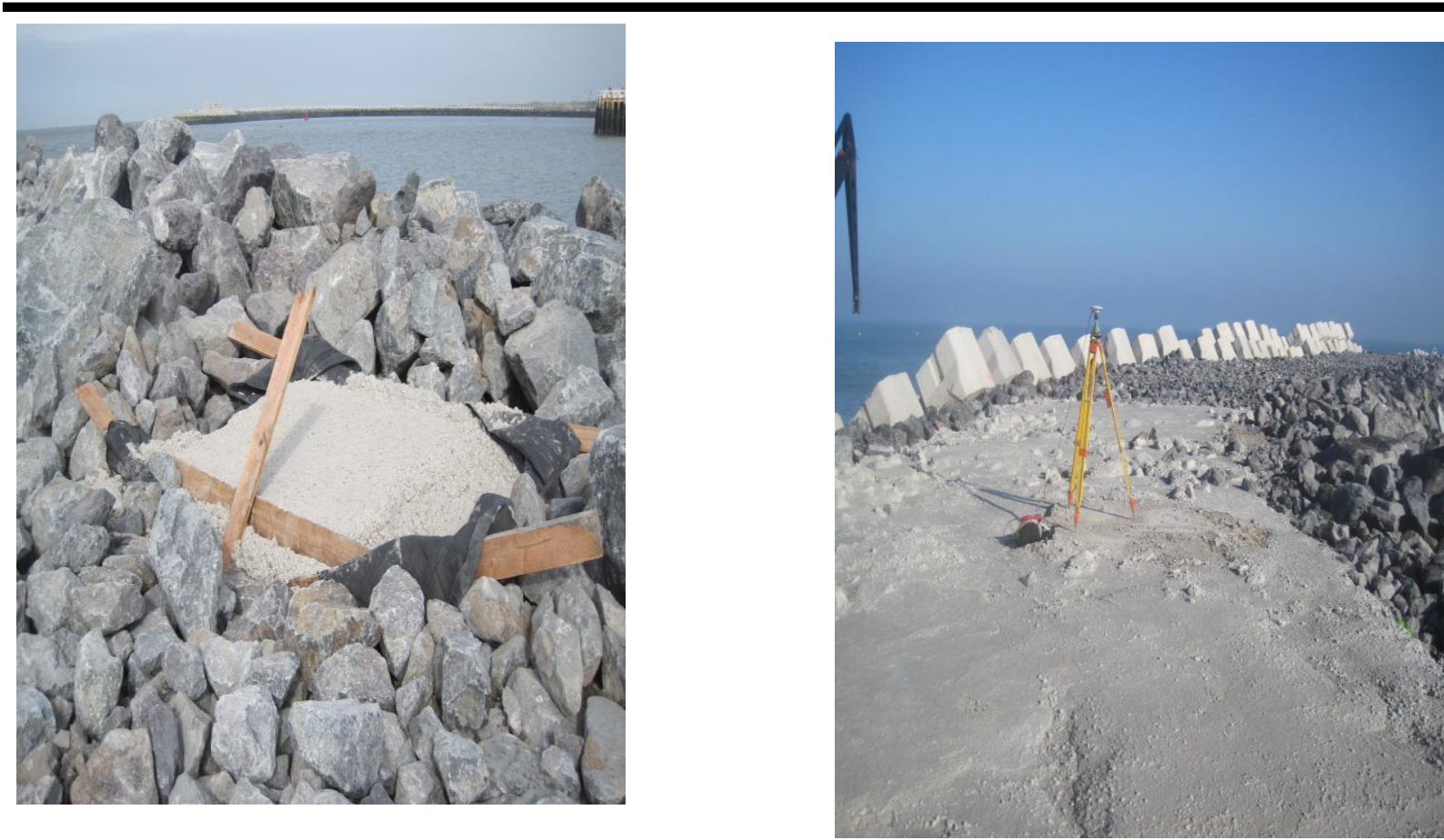

Figure 17: Pictures of settlement block poured in the breakwater and set up of a total station to measure settlements (Omar, 2017).

\subsection{CASE HISTORY OF BREAKWATER DESIGN AND CONSTRUCTION}

The port of Lagos is one of the largest and busiest in Africa and it plays a big role in Nigerian economy. The harbour is protected from the Atlantic Ocean by three breakwaters known as harbour mole. The two largest breakwaters protrude into the ocean and protect the main channel leading ship into the harbour, maintaining the flow of water through the channel and reduce the need for expensive dredging work. Without the breakwater, an ocean surge would be more likely to flood the whole Lagos Island and lagoon causing a massive disruption. For instance in 2012, ocean surge Kuramo beach in Victoria Island flooding the nearby area and claiming the lives of 16people. In 2007, ocean surge in bar beach also cause a major disaster along Ahmadu Bello way causing damages to engineering structures, properties in the vicinity. Although before now Eko Atlantic project has been ongoing in 2003 but due to the disastrous effects of ocean surge on harbour, Lagos state Government order for the demolition of civil structure near bar beach for the full commencement of Eko Atlantics project. The construction of this engineering structure like breakwaters will help reduce the effects of ocean surge, erosion on beaches, flooding and in turn protect the harbor, create opportunities for fishermen and reclaim land from the sea for development and Agricultural purposes. The materials used during the construction the breakwaters are mixture of both rocks (igneous rocks) and concrete material. The diagram below shows the effects of ocean surge on environment. This project is still ongoing till date. 


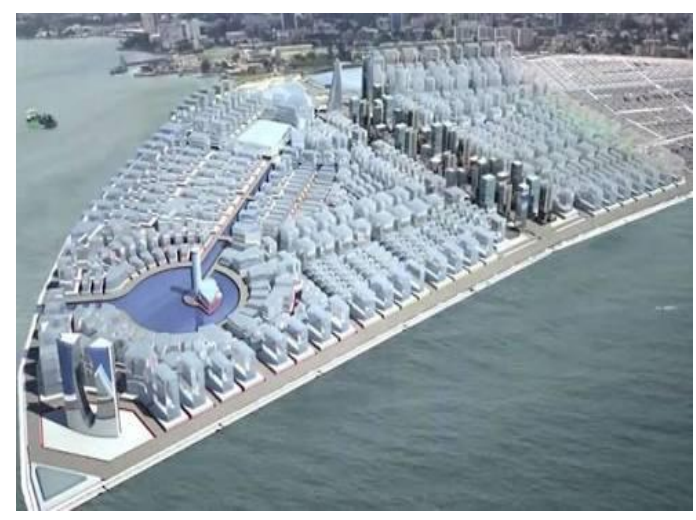

Figure 18: Eko Atlantic dream City project Lekki and Victoria Island Lagos (Omar, 2017)

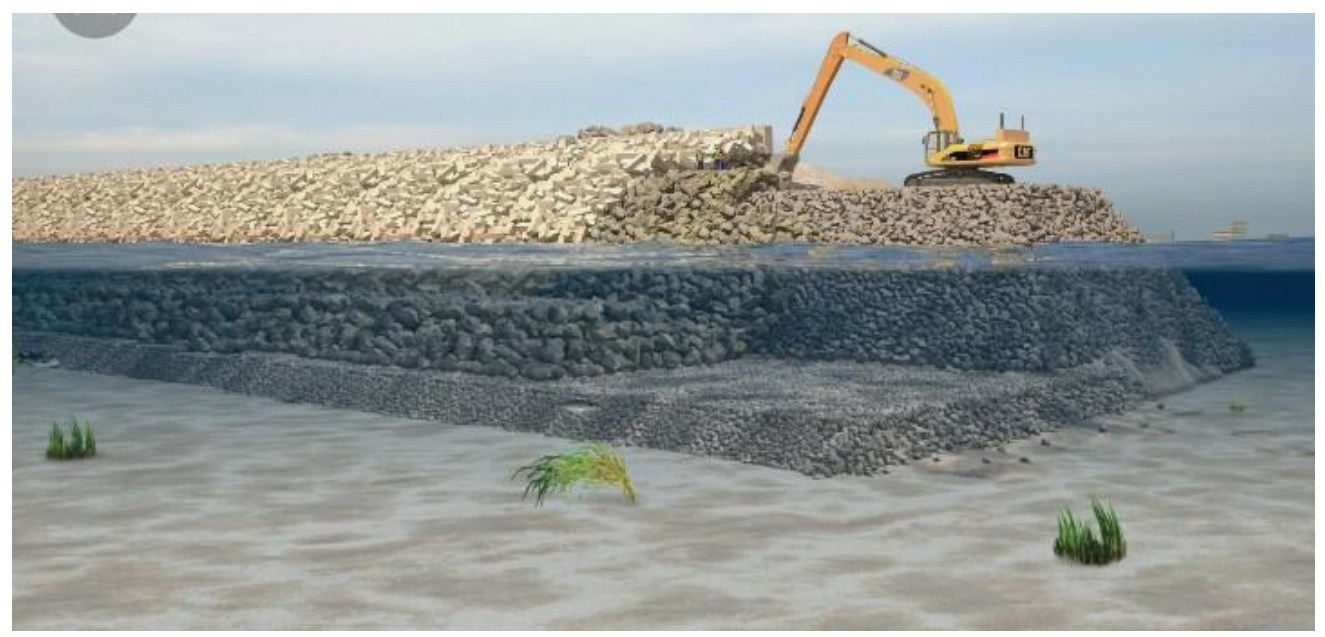

Figure 19: Geotechnical designs of Eko Atlantic project (Omar, 2017) 

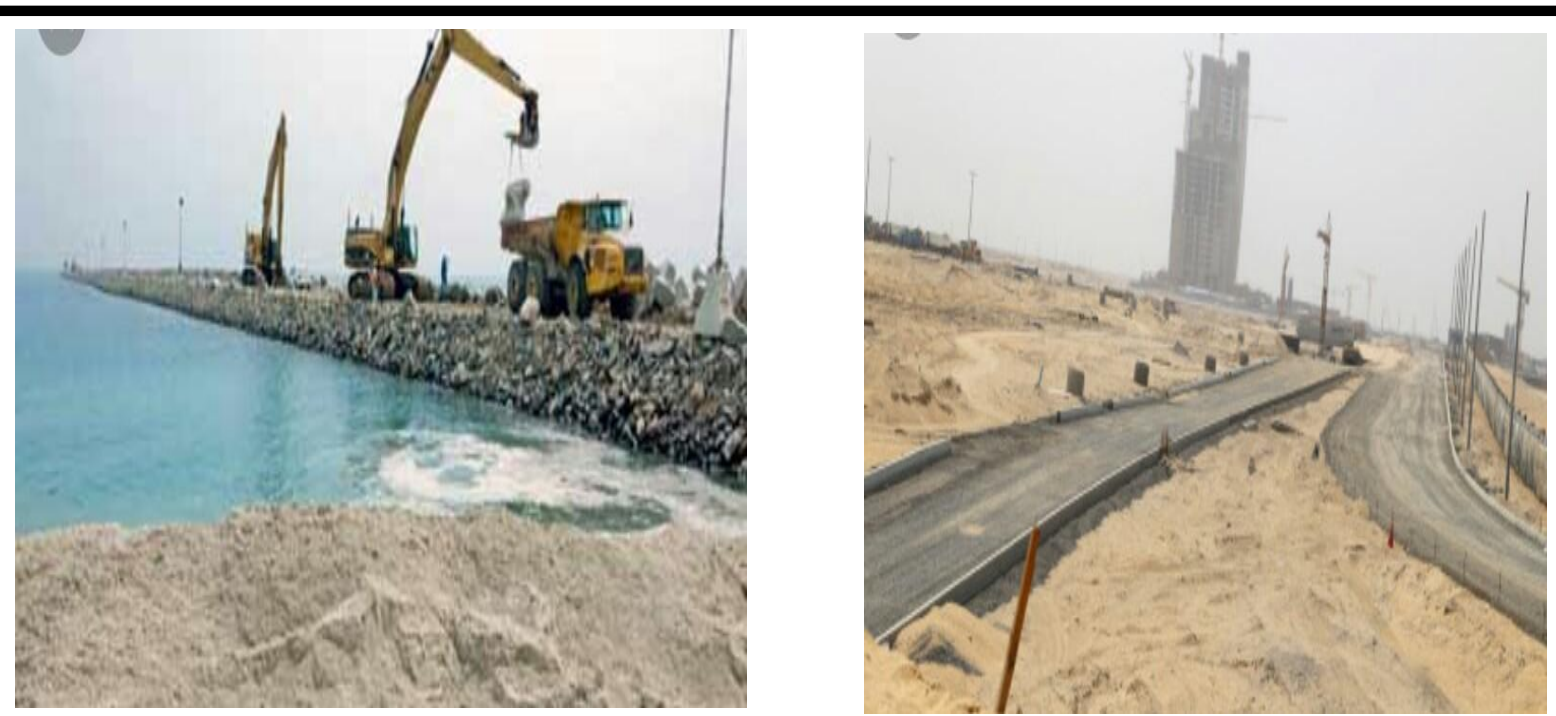

Figure 20: Eko Atlantics Project/Work in progress (Omar, 2017).

\subsection{CONCLUSION AND RECOMMENDATIONS}

Breakwaters are structures constructed in coastal areas to protect ships and shipping facilities (including harbours and navigation channels) from effects of sea/ocean and sedimentation. Other coastal structures that are constructed to serve same or related purposes include: jetties, groins, seawalls, bulkheads and revetments. The three types of breakwaters are: rubble-mound breakwater, vertical-wall or caisson breakwater; and floating breakwater.

Geotechnical aspects of breakwater design and construction refer to use of geotechnical engineering principles and practices in the design and construction of breakwaters. Materials generally used in the construction of breakwaters include: crushed rocks/building stone, soils, concrete and geotextiles (synthetic/plastic fibre).

Highlights of the papers are:

a) Description of some coastal environmental problems such as coastal erosion in North Carolina, USA and flooding (caused by storm surges) of beaches/ residential areas in Lagos, Nigeria.

b) Description of some functional breakwaters that are used in mitigating those environmental problems such as Taconite Harbour Breakwater (Minnesota USA) and Lagos Harbour/Residential Area Breakwater (Lagos, Nigeria)

c) The Recommendations:

i) Detailed geotechnical investigation of the proposed site of any breakwater in terms of nature of foundations and availability of construction of materials for the project should be conducted. 
International Journal of Advanced Academic Research (Sciences, Technology and Engineering)| ISSN: 2488-9849

Journal DOI: 10.46654/ij.24889849

Vol. 6, Issue 12 (December, 2020) | www.ijaar.org

Article DOI: 10.46654/ij.24889849.e61215

ii) Installed breakwaters should be constantly monitored using relevant instruments to evaluate their performance, stability and durability against wave action.

iii) Integrated research on design and construction of breakwaters and other coastal protection structures should be vigorously pursued to ensure improvements in the relevant engineering principles and practices (geotechnical, coastal, environmental and construction engineering) that influence breakwater design and construction. 


\section{REFERENCES}

American Concrete Institute (ACI)(1979), Manual of Concrete Practice, Parts land 3, Detroit.

Arena, F. and Filianti, P. (2007). Small scale experiment on a submerged breakwater for wave energy, dispersion. Journal of Waterway Port, Coastal and Ocean Engineering (March/April, 2001)- 152-160

Barret, R.I. (1996). Use of plastic filters in costal structures Proc. ASCE $10^{\text {th }}$ International Conference on Coastal Engineering 2:1048-1067.

Bird, E.C. F. (1985) Coastline Changes: A global review John Wiley and Sons, New York.

Callender, G. and Eckert, J.W. (1977) Geotechnical Engineering in the Coastal Area. A Special Report US Army Corps of Engineering Research Centre (CERC) Fort Belvior Va USA.

Chandola, S.P. 2001. A. Textbook of Transportation, Engineering S. Chand and Company Ltd. New Boch, India.

Carlson, D.H. and Plummer, C.C. (2009). Physical Geology; Earth Revealed Mcgraw-Hill Book Company, New York.

Coduto, D.P. (1999), Geotechnical Engineering. Prentice Hall Inc. Cliffs, New Jersy.

Deodhar, S.V. (2003) Civil Engineering Meterials. $3^{\text {rd }}$ Edition Khanna Publishers , Nai Sarak Delhi India.

Dolan R and Goodell, H.G. (1986). Sinking cities. American Scientist, 74 (January/February): $38-47$.

Donnell, B. (2006). Effects of breakwater construction on Tedious Creek Small Craft Harbour and Estuary. Maryland Engineering Research and Development Centre, Vicksburg Coastal and Hydraulics Lab.

Dunham, J.W. and Barrett R. J. (1976). Woven plastic cloth filter for stone seawalls. Journal of waterways, Harbour and Costal Engineering Division, ASCE, New York.

Glossop, R. J. (1968). The rise of geotechnology and its influence in engineering practice. $8^{\text {th }}$ Rankine Lecture. Geotechnique, 18(2):107-150.

Iskander, M.M. (2007). Investigating the value of implemented coastal structures alone. EC Agami Beach, Alexandria Egypt: Case study Journal of Coastal Research 26(6): 148301490.

Jarlan, G.L.E. (1961). A Perforated Vertical Harbor. Dock and Harbour Authority 41(April): 394-398.

Krumbein, W.C. (1950). Geological Aspects of Beach Engineering, Berkey Volume. 
Krynine, D. P. and Judd, W.R., (1957). Principles of Engineering Geology and Geotechnic McGraw Hill Book Company, New York.

Machemhl, J.C, French, T. J. and Huang, N.C. (1975). New method for beach erosion control. Proc. ASCE International Conference on Civil Engineering in the oceans (June 912,1925). University of Delaware, New York 1:142-140.

Minikin, R.R., (1950). Winds Wavesd and Maritine Structures Charles Griffen and Co. Ltd. London.

Minikin R.R. (1952) Coastal Erosion and Protection Chapman and Hall Ltd, London.

Moffat and Nichol Engineers, (1981). Low Cost Shore Protection Final Report on Shoreline Erosion Protection Demonstration Program (section 54) US Army Corps of Engineers Costal Engineering Research Centre.

Montgomery, C.W. (2003) Environmental Geology. $6^{\text {th }}$ Edition. Mcgraw Hill Book Company, New York.

Nagi M.A. (2013) Design of breakwater, Department of Irrigation and Hydraulics Faculty of Engineering, Cairo University, Cairo Egypt 17P.

Okeke, O.C. and Akaolisa C.C.Z., (2004) Role of geotechnics in environmental impact studies in the petroleum industry Advances in Geosciences, 2:1-10.

Omar, S, (2017). An appraisal of the maintenance of civil engineering infrastructure in the Nigerian Ports. Research publication University of Nigeria, Nsukka 16P.

Pilkey O.H. (1989). The engineering of sand. Journal of Geological Education 37(November)308-311.

Ranasinghe, R.S. and Sato, S. (2007). Beach Morphology behind single impermeable submerged breakwater under obliquely incident waves. Coastal Engineering Journal, 49(1): 221-227.

Roberts, A. (1981). Geotechnology, Pergamon Press, London.

ShankLand, E.C. (1949). Dredging of Harbour and Rivers $2{ }^{\text {nd }}$ Edition. Brown, Son Ferguson Ltd. London.

US Army Corps of Engineers (1971). Design of Breakwaters and Jetties. Em 1110-2-2904 GPO. Washington D.C.

US Army Corps of Engineers, (1977) Costal Engineering Research Centre shore Protection Manual. $3^{\text {rd }}$ Edition Vols. 1, II and III Stock No 008-022-00113-1, GPO. Washinton D. C.

Van Bendegen, L. and Zanen, A., (1960) Lecture Notes on Revetments. International Course in Hydraulic Engineering, IHE Delft. The Netherlands. 
International Journal of Advanced Academic Research (Sciences, Technology and Engineering)| ISSN: 2488-9849 Vol. 6, Issue 12 (December, 2020) | www.ijaar.org

Journal DOI: 10.46654/ij.24889849

Article DOI: 10.46654/ij.24889849.e61215

Wiezel, R.L. (1962). Diffraction of waves by semi infinite breakwater. Journal of Hydraulic Engineering. ASCE Hydraulic Division (November): 27-44.

William S.J. and Stewart R, (1996) Understanding Coastal wetlands Geotimes (July): 18-22.

Williams S.J. Dodd K, and Goha, K.K. (1997). Costal in Crises. Online version: http://pubs.gov/circular/c1025.

Whiteneck, L.4 and Hockney L. A. (1989). Structural Materials for Harbour and Costal Construction. Mcgraw-Hill Book Company. New York.

http://wikipedia.org/googleimages/breakwaters 